Research Report No. 24/2008

\title{
Judicial Treatment of Indigenous Land Rights in the Common Law World
}

Kent McNeil

Osgoode Hall Law School of York University, kmcneil@osgoode.yorku.ca

Follow this and additional works at: http:// digitalcommons.osgoode.yorku.ca/clpe

\section{Recommended Citation}

McNeil, Kent, "Judicial Treatment of Indigenous Land Rights in the Common Law World" (2008). Comparative Research in Law \& Political Economy. Research Paper No. 24/2008.

http://digitalcommons.osgoode.yorku.ca/clpe/200 


\section{Comparative Research in Law \& Political Economy}

\section{Kent McNeil}

J udicial Treatment of Indigenous Land Rights in the Common Law World

\section{Forthcoming in Indigenous Peoples and the Law: Comparative and Critical Perspectives (Oxford:} Hart Publishing, 2009)

EDITORS: Peer Zumbansen (Osgoode Hall Law School, Toronto, Director, Comparative Research in Law and Political Economy, York University), J ohn W. Cioffi (University of California at Riverside), Lindsay Krauss (Osgoode Hall Law School, Toronto, Production Editor) 

CLPE Research Paper 24/2008

Vol. 04 No. 05 (2008)

\title{
Kent McNeil
}

\section{JUDICIAL TREATMENT OF INDIGENOUS LAND RIGHTS IN THE COMMON LAW WORLD}

\begin{abstract}
This chapter examines the land rights of Indigenous peoples in the United States, Canada, Australia and New Zealand from the perspective of the common law. Topics discussed are sources, content and proof of these rights, as well as ways in which they can be extinguished and infringed. The connection between land rights and self-government of Indigenous peoples is also considered. The chapter takes a critical and comparative approach, pointing out both positive and negative aspects of the judicial treatment of land rights in each of these common law jurisdictions.
\end{abstract}

Keywords: Aboriginal title, Indian title, Indigenous peoples, land rights, native title

JEL classification: K39

Author Contact:

Kent McNeil

Professor, Osgoode Hall Law School, York University 4700 Keele St. Toronto ON, M3J 1P3

Email:kmcneil@osgoode.yorku.ca 


\title{
JUDICIAL TREATMENT OF INDIGENOUS LAND RIGHTS IN THE COMMON LAW WORLD
}

\author{
Kent McNeil ${ }^{*}$
}

\section{INTRODUCTION}

After the so-called 'discovery' of the Americas by Christopher Columbus in 1492, the dominant powers of Europe participated in a competitive rush for colonies that eventually encompassed most of the world. The initial preeminence of Spain and Portugal in this colonial enterprise was later overtaken by the ascent of France and Great Britain, with Britain emerging as the dominant empire-builder at the end of the Seven-Years War in 1763. After World War II, this process was reversed by the decolonization of much of Asia and Africa, where former colonies became independent and joined the international community as nation-states. In other parts of the world, colonies generally known as 'settler colonies' also achieved independence. In these former colonies, European settlers had arrived and reproduced in such numbers that they became the majority of the population. Achievement of nation-state status by these colonies did not result in restoration of the independence of the Indigenous peoples who lived there when the Europeans arrived. Instead, the European settlers remained in control after asserting independence from their mother country. In some cases, this was the result of unilateral assertion, as occurred when the Thirteen Colonies in British North America rebelled in the 1770s and created the United States of America. In other instances, there was a gradual evolution from colonial status to independent nationstate: Canada, Australia, and New Zealand are the leading examples from the British Empire. ${ }^{1}$

* $\quad$ Osgoode Hall Law School, York University, Canada.

See generally WR Louis (ed), The Oxford History of the British Empire, 5 vols (Oxford University Press, 1998-1999); A Calder, Revolutionary Empire: The Rise of the English-Speaking Empires from the Fifteenth Century to the 1780s (rev'd ed, Pimlico, 1998); JH Elliott, Empires of the Atlantic World: Britain and 
Transformation of settler colonies into settler states therefore did not mean decolonization for Indigenous peoples. They continued to be subjected to the domination of the Europeans who had come to their territories. ${ }^{2}$ Politically, the settlers claimed sovereignty, externally against other nation-states and internally over the territory and people of the settler state. They exercised this sovereignty - and continue to do so today through government institutions that were modeled on, or adapted from, the European institutions to which they were accustomed. ${ }^{3}$ Canada, Australia and New Zealand accordingly remained parliamentary monarchies, whereas the United States, in keeping with its rejection of British aristocratic traditions, opted for a republican form of government. Given their historical foundations, geographical extent, and regional diversity, Canada, Australia and the United States also chose federal systems of government, whereby sovereignty is divided internally between a central government (that also exercises external sovereignty) and various states or provinces. However, only the United States acknowledged the internal sovereignty of the Indigenous peoples - the Indian tribes or nations - living within its borders. ${ }^{4}$ Canada, Australia and New Zealand all relied on the British constitutional doctrines of unity of the Crown and parliamentary sovereignty to deny official acknowledgment of even the internal sovereignty of their Indigenous peoples. Only recently have cracks begun to appear in this colonial edifice, as Indigenous peoples in Canada in particular have asserted their inherent right of self-government

Spain in America 1492-1830 (Yale University Press, 2006). On the independence of Canada, Australia and New Zealand, see KC Wheare, The Statute of Westminster and Dominion Status (3rd ed, Oxford University Press, 1947).

2 See chapters by Jennifer Clarke, Jacinta Ruru and Mark Walters.

However, the drafters of the American Constitution were also influenced by Indigenous forms of government, particularly that of the Haudenosaunee (Iroquois Confederacy): see DA Grinde Jr, The Iroquois and the Founding of the American Nation (Indian Historian Press, 1977); BE Johansen, Forgotten Founders: Benjamin Franklin, the Iroquois and the Rationale for the American Revolution (Gambit, 1982); DA Grinde Jr and BE Johansen, Exemplar of Liberty: Native America and the Evolution of Democracy (American Indian Studies Center, University of California, 1991).

See Benjamin J Richardson's chapter on US Indian Law. For judicial affirmation, see Cherokee Nation v Georgia, 30 US (5 Pet) 1 (1831); Worcester v Georgia, 31 US (6 Pet) 515 (1832); US v Lara, 541 US 193 (2004). 
and obtained begrudging, limited acceptance of this right from the Canadian state. ${ }^{5}$

European legal systems - including the law of nations (now international law) developed in Europe to regulate relations among nationstates - distinguish between sovereignty and property rights. Sovereignty involves the exercise of governmental authority over a territory by a polity that asserts and maintains (in principle, if not always in practice) its independence. Externally, sovereignty includes the capacity to enter into relations with other polities that exercise sovereignty over other territories. Internally, it can be equated with jurisdiction, or the authority to make and enforce laws and government policies. Property rights, on the other hand, involve rights in relation to things (corporeal and incorporeal), including land, that arise under and are regulated by domestic laws that generally originate from either practice (customary law) or enactment (positive law). This distinction is vitally important in colonial contexts because acquisition of sovereignty by a colonizing European power did not necessarily entail acquisition of proprietary land rights. ${ }^{6}$

When the European colonizers arrived in North America, they claimed sovereignty vis-à-vis other European powers. But they also entered into treaties with Indigenous nations, some of which acknowledged the sovereignty of those nations. ${ }^{7}$ Other North American treaties involved acquisition of property rights in land, and so were admissions by the Europeans that the Indigenous peoples had such rights. ${ }^{8}$ Similarly in New Zealand, by the 1840 Treaty of Waitangi the British Crown acknowledged the pre-existing sovereignty (at least in the Māori

5 See Shin Imai's chapter, and $\mathrm{K}$ McNeil, 'Judicial Approaches to SelfGovernment since Calder: Searching for Doctrinal Coherence' in H Foster, H Raven and J Webber (eds), Let Right Be Done: Aboriginal Title, the Calder Case, and the Future of Indigenous Rights (UBC Press, 2007) 129.

6 See M de Vattel, The Law of Nations, or the Principles of Natural Law, trans of 1758 edn by CG Fenwick (Carnegie Institution, 1916) bk I, c 18, ss 204-5; K Roberts-Wray, Commonwealth and Colonial Law (Stevens and Sons, 1966) 99, 625-36.

$7 \quad$ Eg the Two-Row-Wampum Treaty with the Haudenosaunee: see M Mitchell, 'An Unbroken Assertion of Sovereignty' in B Richardson (ed), Drumbeat: Anger and Renewal in Indian Country (Summerhill Press, 1989) 107, 109-11. See also RA Williams Jr, Linking Arms Together: American Indian Treaty Visions of Law and Peace, 1600-1800 (Oxford University Press, 1997).

$8 \quad$ See Mark Walters' chapter. 
version of the Treaty) and land rights of the Māori. ${ }^{9}$ Nonetheless, the British Crown claimed that its own acquisition of sovereignty over a territory included underlying title to all the land, and courts have consistently upheld this claim. ${ }^{10}$ The same rule has been applied in Australia, where no treaties have been acknowledged and there was no judicial recognition of Indigenous land rights (apart from statute) until 1992. ${ }^{11}$

This chapter focuses on the common law land rights of the Indigenous peoples in the United States, Canada, Australia and New Zealand. These former settler colonies share a common British heritage, and all have legal systems that are based on English law. Despite these commonalities, the law in relation to Indigenous land rights has developed in distinctive ways in each of these jurisdictions. The connection between land rights and Indigenous sovereignty has also been dealt with differently. As already mentioned, American law recognized early on that land rights and internal sovereignty are both aspects of Indigenous territorial rights, while the other three jurisdictions have been reluctant to acknowledge this connection.

The discussion is structured thematically rather than geographically. Topics covered are the sources, content and proof of Indigenous land rights, and the ways in which they can be extinguished and infringed. The focus is on judicial treatment of these matters, rather than on legislation and negotiated agreements. ${ }^{12}$ Comparisons of the law in

$9 \quad$ See Jacinta Ruru's chapter, and C Orange, The Treaty of Waitangi (Allen and Unwin/Port Nicholson Press, 1987); P McHugh, The Māori Magna Carta: New Zealand Law and the Treaty of Waitangi (Oxford University Press, 1991); M Belgrave, M Kawharu and D Williams (eds), Waitangi Revisited: Perspectives on the Treaty of Waitangi (Oxford University Press, 2005).

$10 \quad$ See St Catherine's Milling and Lumber Company v The Queen (1888) 14 App Cas 46 (PC); Delgamuukw v British Columbia [1997] 3 SCR 1010; Te Runanga o Wharekauri Rekohu Inc v Attorney-General [1994] 2 NZLR 20, 23-24 (CA); Attorney-General v Ngati Apa [2003] 3 NZLR 643 (CA).

11 By Mabo $v$ Queensland [No 2] (1992) 175 CLR 1 (HC Aust). For evidence of an unacknowledged treaty in Tasmania, see H Reynolds, Fate of a Free People: A Radical Re-Examination of the Tasmanian Wars (Penguin Books, 1995). On statutory land rights, which will not be dealt with here, see Jennifer Clarke's chapter.

12 For statutory and agreement-based rights, see chapters by Jennifer Clarke, Shin Imai, Benjamin J Richardson and Jacinta Ruru. Resolution of land claims is dealt with in Michael Coyle's chapter. 
the four jurisdictions under consideration are undertaken in relation to each of the topics covered. While this comparative analysis is meant to be critical, it nonetheless examines these matters from the perspective of the dominant legal system in each jurisdiction, which is based on English common law. I realize that this involves making a choice of law. This is not intended to reflect negatively on the relevance or validity of Indigenous legal systems. ${ }^{13}$ Instead, it is an acknowledgement of the limitations of my own knowledge and expertise as a non-Indigenous academic, and of the fact that, with the exception of tribal and peacemaker courts in the United States, the law of Indigenous rights has been formulated and applied primarily by common law courts.

\section{SOURCES OF INDIGENOUS LAND RIGHTS}

While the existence of Indigenous land rights has long been acknowledged by governments and courts in the United States, Canada and New Zealand, and more recently in Australia, the sources of these rights have not always been clear. One possibility is that these rights arise from the Indigenous legal systems that were in place when the European colonizers arrived. According to established principles of British colonial and international law, when the Crown acquired sovereignty over a territory the land rights of the local peoples under their own systems of law continued, and became enforceable in common law courts, through what is known as the doctrine of continuity. ${ }^{14} \mathrm{~A}$ second possibility is that the common law itself acknowledged that use and occupation of land by Indigenous peoples at the time of Crown acquisition of sovereignty gave rise to real property

13 See chapters by John Borrows and Christine Zuni Cruz, and Borrows' book, Recovering Canada: The Resurgence of Indigenous Law (University of Toronto Press, 2002).

14 See M Walters, "The "Golden Thread" of Continuity: Aboriginal Customs at Common Law and under the Constitution Act, 1982' (1999) 44 McGill Law Journal 711; RL Barsh, 'Indigenous Rights and the Lex Loci in British Imperial Law' in $\mathrm{K}$ Wilkins (ed), Advancing Aboriginal Claims: Visions/Strategies/Directions (Purich Publishing, 2004) 91; Vattel, above n 6, bk III, c 13, ss 200-1; PD O'Connell, State Succession in Municipal and International Law (Cambridge University Press, 1967) vol I, 237-50. 
rights. ${ }^{15}$ This alternative should be available to any Indigenous occupants, whether or not they had land rights under their own pre-existing systems of law. ${ }^{16}$ Thirdly, Indigenous land rights may have been based on the law of nations, as applied by domestic courts. A fourth possibility is that Indigenous land rights arose after Crown acquisition of sovereignty, through a positive act of creation by the Crown or a legislative body. ${ }^{17}$

In North America, the British Crown purchased Indigenous lands by treaty, a practice that was formalized by the Royal Proclamation of 1763. ${ }^{18}$ In its decision in St Catherine's Milling and Lumber Company $v$ The Queen ${ }^{19}$ in 1888, the Judicial Committee of the Privy Council suggested that the Royal Proclamation was the source of Indigenous land rights in British North America, but in 1973 the Supreme Court of Canada in Calder v Attorney-General of British Columbia ${ }^{20}$ decided that this was not the sole source. Justice Judson put it this way:

Although I think that it is clear that Indian title in British Columbia cannot owe its origin to the Proclamation of 1763 , the fact is that when the settlers came, the Indians were there, organized in societies and occupying the land as their forefathers had done for centuries. This is what Indian title means....

While this passage indicated that occupation of land can be a source of Indigenous land rights, the words 'organized in societies' implied a further requirement. $^{22}$

The notion that any people could exist without being socially organized attracted considerable criticism, ${ }^{23}$ and was notably absent from

15 See K McNeil, Common Law Aboriginal Title (Clarendon Press, 1989) esp 196221.

Ibid, 193-96.

A fifth potential source not discussed here is natural law or fundamental principles of justice: see B Slattery, 'Aboriginal Sovereignty and Imperial Claims’ (1991) 29 Osgoode Hall Law Journal 681.

See Mark Walters' chapter.

Above $\mathrm{n} 10$.

[1973] SCR 313.

Ibid, 328.

See Baker Lake v Minister of Indian Affairs [1980] 1 FC 518 (FCTD), 557.

Eg see C Bell and M Asch, 'Challenging Assumptions: The Impact of Precedent in Aboriginal Rights Litigation' in M Asch (ed), Aboriginal and Treaty Rights in 
the Supreme Court's subsequent reassessment of Aboriginal title in Delgamuukw v British Columbia. ${ }^{24}$ Chief Justice Lamer stated:

It had originally been thought that the source of aboriginal title in Canada was the Royal Proclamation, 1763: see St. Catherine's Milling. However, it is now clear that although aboriginal title was recognized by the Proclamation, it arises from the prior occupation of Canada by aboriginal peoples. $^{25}$

He went on to explain that there are two ways in which prior occupation is relevant. First, in the common law physical occupation is proof of possession, which in turn grounds title. He thus accepted the second potential source we identified earlier. ${ }^{26}$ But he also suggested another 'source for aboriginal title - the relationship between common law and pre-existing systems of aboriginal law'. ${ }^{27}$ However, he does not seem to have meant by this that Aboriginal title is derived from Aboriginal law and the application of the doctrine of continuity. Instead, when elaborating on proof of Aboriginal title, he clarified that both physical occupation and Aboriginal law can be relied upon to establish the exclusive occupation at the time of Crown assertion of sovereignty that is necessary to prove title. Moreover, as discussed in more detail below, he regarded Aboriginal title as a generic right that does not vary from one Aboriginal group to another, as it would if it were based on the continuation of rights under vastly different systems of Aboriginal law. ${ }^{28}$ However, it is nonetheless conceivable that the Chief Justice meant to leave the door open for Indigenous peoples to claim title on the basis of their own laws, as an alternative to occupation-based title.

\footnotetext{
Canada: Essays on Law, Equality, and Respect for Difference (UBC Press, 1997) 38 .

Above $\mathrm{n} 10$.

Ibid, para 114 .

In $R$ v Marshall; $R$ v Bernard [2005] 2 SCR 220, the Supreme Court reaffirmed that occupation of land at the time of Crown sovereignty is the source of Aboriginal title. See also Tsilhqot'in Nation v British Columbia [2008] 1 CNLR 112 (BCSC).

27 Delgamuukw, above n 10, para 114.

28 See B Slattery, 'A Taxonomy of Aboriginal Rights' in Foster, Raven and Webber, above n 5, 111.
} 
The Canadian Supreme Court has distinguished Aboriginal title from more limited Aboriginal rights to harvest resources - such as fish, game and timber for domestic use - from specific lands. ${ }^{29}$ These rights stem, not from exclusive occupation of land, but from practices, customs and traditions in relation to harvesting that were integral to distinctive Aboriginal cultures at the time of contact with Europeans ${ }^{30}$ (or, for the Métis, effective European control ${ }^{31}$ ). In this context, customs can include Aboriginal law, ${ }^{32}$ but the Supreme Court has not applied the doctrine of continuity as such in identifying and enforcing these land rights. ${ }^{33}$

Turning to the United States, the Supreme Court acknowledged the existence of Aboriginal or Indian title early in the $19^{\text {th }}$ century. ${ }^{34}$ In the famous case of Johnson $v$ M'Intosh, ${ }^{35}$ Chief Justice Marshall regarded occupation as the basis for this title, but not in the way the Canadian Supreme Court did later in Delgamuukw. Instead of applying the common law property rule that physical occupation of land is proof of possession and title, Marshall CJ relied on his understanding of the doctrine of discovery in the law of nations. ${ }^{36}$ He explained that, on discovering North

$29 \quad$ Eg see $R v$ Adams [1996] 3 SCR 101; $R$ v Côté [1996] 3 SCR 139; $R v$ Sappier; $R v$ Gray [2006] 2 SCR 686.

$R v$ Van der Peet [1996] 2 SCR 507. For critical commentary, see J Borrows, 'Frozen Rights in Canada: Constitutional Interpretation and the Trickster' (1997) 22 American Indian Law Review 37; RL Barsh and JY Henderson, 'The Supreme Court's Van der Peet Trilogy: Naive Imperialism and Ropes of Sand' (1997) 42 McGill Law Journal 993; CC Cheng, 'Touring the Museum: A Comment on R. $v$ Van der Peet' (1997) 55 University of Toronto Faculty of Law Review 419. $R v$ Powley [2003] 2 SCR 207. The Métis, who originated as a distinct people from intermarriage between Aboriginal women and European fur-traders, are one of the three Aboriginal peoples (Indians and Inuit are the others) whose Aboriginal rights were recognized and affirmed by s 35 of the Constitution Act, 1982, being Schedule B to the Canada Act 1982 (UK), 1982, c 11. See PLAH Chartrand (ed), Who Are Canada's Aboriginal Peoples? Recognition, Definition, and Jurisdiction (Purich Publishing, 2002).

32 See Sappier and Gray, above n 29, para 45.

33 For critical analysis, see $\mathrm{K}$ McNeil and D Yarrow, 'Has Constitutional Recognition of Aboriginal Rights Adversely Affected Their Definition?' (2007) 37 Supreme Court Law Review (2d) 177, esp 204-11.

$34 \quad$ See Fletcher $v$ Peck, 10 US (6 Cranch) 87 (1810), 142-43.

3521 US (8 Wheat) 543 (1823). For detailed background and analysis, see LG Robertson, Conquest by Law: How the Discovery of America Dispossessed Indigenous Peoples of Their Lands (Oxford University Press, 2005).

36 See RJ Miller, Native America, Discovered and Conquered: Thomas Jefferson, Lewis and Clark, and Manifest Destiny (Praeger Publishers, 2006). 
America, the major European states all wanted to acquire as much of it as they could, but, to reduce conflicts among themselves, they all agreed 'that discovery gave title to the government by whose subjects, or by whose authority, it was made, against all other European governments, which title might be consummated by possession'. ${ }^{37}$ As a result, the pre-existing sovereignty and land rights of the Indian nations were reduced:

They were admitted to be the rightful occupants of the soil, with a legal as well as just claim to retain possession of it, and to use it according to their own discretion; but their rights to complete sovereignty, as independent nations, were necessarily diminished, and their power to dispose of the soil at their own will, to whomsoever they pleased, was denied by the original fundamental principle, that discovery gave exclusive title to those who made it. ${ }^{38}$

Indian title thus became a right of occupancy through application of what Marshall CJ considered to be an international principle, which he applied domestically. Indian law was not the source of this title, though in his view this law continued to apply internally within the Indian territories. ${ }^{39}$

Marshall CJ's reliance on the law of nations rather than on the common law of property or Indigenous law reveals a fundamental difference between the United States and Canada. In American law, Indian title is not just a proprietary right to land. It really amounts to title to territory, which includes governmental authority as well as land rights. So the Indian nations have retained residual sovereignty over their territories

37 Johnson, above n 35, 573. Marshall CJ undoubtedly got this wrong, as there was no agreement among European nations during the colonial period on the requirements for obtaining territorial sovereignty in the Americas: see MF Lindley, The Acquisition and Government of Backward Territory in International Law (Longmans, Green and Co, 1926); J Goebel Jr, The Struggle for the Falkland Islands: A Study in Legal and Diplomatic History (1927, reissued Kennikat Press, 1971), 47-119; P Seed, Ceremonies of Possession in European Conquest of the New World, 1492-1640 (Cambridge University Press, 1995); B Slattery, 'Paper Empires: The Legal Dimensions of French and English Ventures in North America' in J McLaren, AR Buck and NE Wright (eds), Despotic Dominion: Property Rights in British Settler Societies (UBC Press, 2005) 50.

38 Johnson, above n 35, 574.

39 Ibid, 593. See also the cases cited in $\mathrm{n} 4$ above. 
as 'domestic dependent nations' within the United States. ${ }^{40}$ In Canada, land rights and self-government have been treated as separate issues by the Supreme Court, ${ }^{41}$ though we shall see later that Aboriginal title does have jurisdictional dimensions that have been acknowledged by the British Columbia Supreme Court. ${ }^{42}$

In Australia and New Zealand, Indigenous law has played a more prominent role as a source of Aboriginal title to land. Prior to the High Court's decision in Mabo $v$ Queensland [No 2], ${ }^{43}$ the sole judiciallyacknowledged source of Indigenous land rights in Australia was legislation, enacted in the Northern Territory and most states to address the denial of land rights in Milirrpum v Nabalco Pty. ${ }^{44}$ In Mabo, the Court reassessed this matter, and concluded that the Indigenous peoples of Australia did indeed have native title (the Australian term for Indigenous land rights) to lands they occupied under their traditional laws and customs at the time the British Crown acquired sovereignty. Applying this conclusion to the Miriam People of the Murray Islands in the Torres Strait, the Court declared that they 'are entitled as against the whole world to possession, occupation, use and enjoyment of the lands of the Murray Islands'. ${ }^{4}$

Although there was no evidence of the communal title that the Court apparently declared the Miriam People to have, ${ }^{46}$ in his judgment

$40 \quad$ Cherokee Nation, above n 4, 17. See also Worcester, above n 4.

41 See Delgamuukw, above n 10; $R$ v Pamajewon [1996] 2 SCR 821. Compare Mitchell v MNR [2001] 1 SCR 911, per Binnie J, and discussion in McNeil, above n 5, 143-52. For critical analysis, see K McNeil, 'Aboriginal Rights in Canada: From Title to Land to Territorial Sovereignty' (1998) 5 Tulsa Journal of Comparative and International Law 253, reprinted in K McNeil, Emerging Justice? Essays on Indigenous Rights in Canada and Australia (Native Law Centre of Canada, 2001) 58.

$42 \quad$ In Campbell v British Columbia [2000] 4 CNLR 1.

43 Above n 11. For background and analysis, see PH Russell, Recognizing Aboriginal Title: The Mabo Case and Indigenous Resistance to English-Settler Colonialism (University of Toronto Press, 2005).

44 (1971) 17 FLR 141 (NTSC). See McNeil, above n 15, 290-97; H McRae et al (eds), Indigenous Legal Issues: Commentary and Materials (3rd ed, Lawbook Co, 2003) 184-86, 204-30.

$45 \quad$ Mabo, above n 11, Order of the Court, 217.

46 Moynihan J, the judge who made the factual findings, had 'found that there was apparently no concept of public or general community ownership among the people of Murray Island, all the land on Murray Island being regarded as belonging to individuals or groups': ibid, 22. 
Justice Brennan included the following general statement about the source of native title that has become entrenched in Australian law:

Native title has its origin in and is given its content by the traditional laws acknowledged by and the traditional customs observed by the indigenous inhabitants of a territory. $^{47}$

Despite the evident contradiction between this statement and the absence of traditional laws and customs supporting the communal title declared by the Court, ${ }^{48}$ the Australian Parliament adopted Brennan J's statement in the Native Title Act 1993 (Cth), ${ }^{49}$ which was enacted to validate preexisting, non-Indigenous land rights and provide a mechanism for resolution of native title claims. Section 223(1) of that Act provides:

223. (1) The expression 'native title' or 'native title rights and interests' means the communal, group or individual rights and interests of Aboriginal peoples or Torres Strait Islanders in relation to land or waters, where:

(a) the rights and interests are possessed under the traditional laws acknowledged, and the traditional customs observed, by the Aboriginal peoples or Torres Strait Islanders; and

(b) the Aboriginal peoples or Torres Strait Islanders, by those laws and customs, have a connection with the land or waters; and

(c) the rights and interests are recognised by the common law of Australia.

48 See K McNeil, 'The Relevance of Traditional Laws and Customs to the Existence and Content of Native Title at Common Law' in Emerging Justice?, above n 41, 416, 418-22. Amendment Act 2007 (Cth). For detailed discussion, see McRae, above n 44, esp 247-376; RH Bartlett, Native Title in Australia (2nd ed, LexisNexis Butterworths, 2004).
} 
In subsequent judgments, the High Court has relied upon this statutory definition, and required strict proof of Indigenous laws and customs supporting claimed land rights at the time of Crown acquisition of sovereignty, as well as proof that these laws and customs have been maintained up to the present day. ${ }^{50}$

In New Zealand, Māori land rights were acknowledged by the British Crown in the 1840 Treaty of Waitangi, the English version of which guaranteed to the Māori 'the full exclusive and undisturbed possession of their Lands and Estates Forests Fisheries and other properties'. ${ }^{51}$ Judicial acknowledgement followed soon after, in the 1847 decision of the NZ Supreme Court in the Queen $v$ Symonds. ${ }^{52}$ In Nireaha Tamaki $v$ Baker ${ }^{53}$ the Privy Council approved of the Symonds decision, and rejected a contrary opinion expressed by another New Zealand judge that 'there is no customary law of the Maoris of which the Courts of Law can take cognizance'. ${ }^{54}$ On the contrary, the Privy Council said that the statutory regime put in place to integrate Māori title into the English landholding system 'plainly assumes the existence of a tenure of land under custom and usage'. ${ }^{55}$ This view that Māori land rights have their source in Māori custom and usage (tikanga Māori) has recently been affirmed by the NZ Court of Appeal in Attorney-General v Ngati Apa. ${ }^{56}$

Eg see Fejo v Northern Territory (1998) 195 CLR 128; Commonwealth v Yarmirr [2001] 208 CLR 1; Western Australia v Ward (2002) 213 CLR 1; Members of the Yorta Yorta Community v Victoria (2002) 214 CLR 422. For critical analysis, see L Strelein, Compromised Jurisprudence: Native Title Cases Since Mabo (Aboriginal Studies Press, 2006); S Dorsett, 'An Australian Comparison on Native Title to the Foreshore and Seabed' in C Charters and A Erueti (eds), Māori Property Rights in the Foreshore and Seabed: The Last Frontier (Victoria University Press, 2007) 59; S Young, The Trouble with Tradition: Native Title and Cultural Change (Federation Press, 2008).

$51 \quad$ Art 2. The Treaty is reproduced in the First Schedule to the Treaty of Waitangi Act, NZS 1975, No 114. For detailed analysis, see works cited above in n 9. [1840-1932] NZPCC 387. [1901] AC 561. Prendergast CJ in Wi Parata v Bishop of Wellington (1877) 3 NZ Jur (NS) SC 72.

$55 \quad$ Nireaha Tamaki, above n 53, 577.

56 Above $\mathrm{n}$ 10. See Jacinta Ruru's chapter. 
The doctrine of continuity has thus been applied in New Zealand, but less rigidly than in Australia. ${ }^{57}$ Māori land rights are sourced, not just in traditional laws and customs, but also in practice and usage, rendering bright-line distinctions between law/custom and practice/usage unnecessary. ${ }^{58}$ This approach also avoids the problem that Indigenous claimants have faced in Australia of having to prove that they had a normative system prior to Crown acquisition of sovereignty that generated 'rights' cognizable to non-Indigenous Australian judges. ${ }^{59}$

\section{CONTENT OF INDIGENOUS LAND RIGHTS}

Indigenous land rights are sui generis - they are different from other interests in land under the common law. There are also variations in the nature of these rights in each of the four jurisdictions under consideration here. These variations are largely due to the different sources of these rights examined in the previous section. The content of land rights rooted in occupation and use is not the same as content stemming from traditional laws and customs. The right of occupancy of the Indian nations in the United States also has unique features arising from American constitutionalism and the US Supreme Court's application of the doctrine of discovery.

In Canada, we have seen that the Supreme Court held in Delgamuukw that Aboriginal title arises from exclusive occupation of land at the time of Crown assertion of sovereignty. At common law, exclusive occupation usually results in a fee simple estate, which, apart from Crown title, is the largest permissible interest in land. ${ }^{60}$ However, given its unique source in occupation pre-dating Crown sovereignty, and other sui generis aspects (such as inalienability and communal nature, to be discussed below), the Court declined to equate Aboriginal title with a fee simple estate. But despite arguments by counsel for the Crown, the Court

57 See Young, above n 50, esp 167-200. For recent application of this doctrine in another common law jurisdiction, see Cal v Attorney General of Belize; Coy $v$ Attorney General of Belize, Claim Nos 171 and 172 of 2007, SC of Belize.

58 See K McNeil, 'Legal Rights and Legislative Wrongs: Māori Claims to the Foreshore and Seabed' in Charters and Erueti, above n 50, 83, esp 87-89.

59 See Yorta Yorta, above n 50. For critical analysis, see McNeil, above n 48; Young, above n 50.

$60 \quad$ See McNeil, above n 15, 6-9, 198. 
also refused to limit Aboriginal title to traditional uses. Chief Justice Lamer stated:

I have arrived at the conclusion that the content of aboriginal title can be summarized by two propositions: first, that aboriginal title encompasses the right to exclusive use and occupation of the land held pursuant to that title for a variety of purposes, which need not be aspects of those aboriginal practices, customs and traditions which are integral to distinctive aboriginal cultures; and second, that those protected uses must not be irreconcilable with the nature of the group's attachment to that land. ${ }^{61}$

This means that Aboriginal title includes the natural resources on and under the land, including standing timber and oil and gas, regardless of whether the Aboriginal titleholders used these resources in the past. ${ }^{62}$ It also means that they have the right to prevent third parties from trespassing on their land. ${ }^{63}$

Chief Justice Lamer's second proposition placed an inherent limit on the uses Aboriginal titleholders can make of their lands that was intended to preserve the land for future generations. Elaborating, he said that 'lands subject to aboriginal title cannot be put to such uses as may be irreconcilable with the nature of the occupation of that land and the relationship that the particular group has had with the land which together have given rise to aboriginal title in the first place'. ${ }^{64}$ As examples of situations where this limit might apply, he suggested that Aboriginal titleholders might not be able to strip-mine their traditional hunting grounds or convert a ceremonial site into a parking lot.

Although well-intentioned, the inherent limit the Court placed on uses of Aboriginal title land was without precedent, and could seriously impede beneficial economic development by Aboriginal communities. It is also paternalistic, shifting authority to protect Aboriginal lands from

\footnotetext{
$61 \quad$ Delgamuukw, above n 10, para 117.

62 Ibid, para 119-24; Tsilhqot'in Nation, above n 26, para 971-81.

63 See K McNeil, Defining Aboriginal Title in the 90's: Has the Supreme Court Finally Got It Right? (Robarts Centre for Canadian Studies, York University, 1998) 8-11.

64 Delgamuukw, above n 10, para 128.
} 
communities to Canadian judges. ${ }^{65}$ Given the long history of exploitation of Aboriginal lands and removal of natural resources for the benefit of colonial interests, one has to wonder who is better placed to ensure the protection of these lands for future generations. ${ }^{66}$

In addition to this inherent limit and Aboriginal title's unique source in occupation prior to Crown sovereignty, Chief Justice Lamer identified two further sui generis aspects: inalienability and communal nature. ${ }^{67}$ In each of the four jurisdictions under consideration, courts have consistently held that Aboriginal title cannot be sold or otherwise transferred to anyone other than the Crown, or, in the United States, the American government. ${ }^{68}$ This is a matter of both law and policy. ${ }^{69}$ Various reasons have been given for this inalienability, including protection of Indigenous peoples from exploitation, incapacity of private persons to acquire title other than by government grant, and a need for government control of settlement. While each of these explanations has some validity, I think a more fundamental reason is that, unlike private property interests, Aboriginal title has jurisdictional dimensions that cannot be transferred to private persons, and so only another government can acquire the title. ${ }^{70}$

In Delgamuukw, the Supreme Court took a distinctly propriety approach to Aboriginal title, without explicitly considering its jurisdictional dimensions. Although the Gitksan and Wet'suwet'en peoples who brought the action had asked the Court for a declaration of their right of self-government as well as of their title, the Court regarded self-government as a separate matter, and decided not to deal with it directly. $^{71}$ Significantly, however, in reference to the communal nature of Aboriginal title, Chief Justice Lamer observed:

65 For critical discussion, see $\mathrm{K}$ McNeil, 'The Post-Delgamuukw Nature and Content of Aboriginal Title' in Emerging Justice?, above n 41, 102, 116-22.

66 See Benjamin J Richardson's Environmental Governance chapter.

67 See McNeil, above note 15, 221-35; McNeil, above n 65, 122-35.

$68 \quad$ Eg see Johnson, above n 35; Symonds, above n 52; Mabo, above n 11.

69 The Royal Proclamation of 1763 prohibited private purchases of Indian lands in British North America, and the 1840 Treaty of Waitangi affirmed the Crown's right of pre-emption of Māori lands in New Zealand: see chapters by Mark Walters and Jacinta Ruru.

70 See K McNeil, 'Self-Government and the Inalienability of Aboriginal Title' (2002) 47 McGill Law Journal 473.

71 Delgamuukw, above n 10, para 170-71. 


\begin{abstract}
Aboriginal title cannot be held by individual aboriginal persons; it is a collective right to land held by all members of an aboriginal nation. Decisions with respect to that land are also made by that community. ${ }^{72}$
\end{abstract}

In addition to attributing legal personality to Aboriginal nations, ${ }^{73}$ this brief passage does contain an indirect acknowledgement of the jurisdictional dimensions of Aboriginal title. As recognized by Justice Williamson of the BC Supreme Court in Campbell v British Columbia, ${ }^{74}$ where title is held communally by an Aboriginal group that has decisionmaking authority, there must be a political structure for exercising that authority. In other words, communal title and decision-making authority necessitate self-government, at least in relation to Aboriginal title land. ${ }^{75}$

Before discussing the other three jurisdictions, mention needs to be made of the content of Aboriginal land rights in Canada apart from title. In a number of cases, the Supreme Court has held that Aboriginal peoples can have site-specific rights to harvest resources, even though they do not have title to the land itself. ${ }^{76}$ In Sappier and Gray, ${ }^{77}$ for example, the Court held that the Maliseet and Mi'kmaq peoples in New Brunswick have an Aboriginal right to harvest wood for domestic purposes, such as constructing houses and making furniture for themselves. The content of these resource-use rights is determined by practices, customs and traditions that were integral to the distinctive culture of the people in question at the time of contact with Europeans. ${ }^{78}$

Turning to the United States, the Supreme Court's approach to Aboriginal title has never been strictly proprietary. Ever since Johnson $v$ M'Intosh $^{79}$ was decided in 1823 , Indian title has been inseparable from

\footnotetext{
$72 \quad$ Ibid, para 115 .

73 This is an exception to the common law rule that unincorporated collectivities are not legal persons and so cannot hold property: see McNeil, above n 65, 12225 .

$74 \quad$ Above n 42, para 137-38.

75 See McNeil, above n 5, 139-43.

76 See cases cited above in n 29, and K McNeil, 'Aboriginal Title and Aboriginal Rights: What's the Connection?' (1997) 36 Alberta Law Review 117.

$77 \quad$ Above $\mathrm{n} 29$.

78 See Van der Peet, above n 30, and the articles cited in that note.

$79 \quad$ Above $\mathrm{n} 35$.
} 
Indian sovereignty. In the two Cherokee Nation cases in the early $1830 \mathrm{~s}$, ${ }^{80}$ Chief Justice Marshall affirmed that, after European colonization and subsequent incorporation of their territories into the United States, the Indian nations retained not only their lands, but also their internal sovereignty. Indian title therefore has jurisdictional dimensions that make it more akin to title to territory than to title to land: Indian nations exercise jurisdiction over their tribal lands in the same way other sovereigns exercise jurisdiction over lands within their territories. ${ }^{81}$ It follows that Indian nations have a plenary, collective interest in their lands that includes all surface and subsurface rights. ${ }^{82}$ Moreover, in exercising their sovereignty they can make laws providing for the creation of individual and other property rights within their territories, but the restriction on alienation mentioned above prevents them from selling their lands so that they would be removed from their territory and hence their jurisdiction, unless the purchaser is the United States. ${ }^{83}$ Furthermore, unlike Aboriginal title in Canada, Indian title is not subject to an inherent limit restricting the uses Indian nations can make of their lands.

The US Supreme Court's jurisdictional approach to Indian land rights has had a down-side for the Indian nations. In Tee-Hit-Ton Indians $v$

Cherokee Nation and Worcester, above n 4. See J Norgren, The Cherokee Cases: The Confrontation of Law and Politics (McGraw-Hill, 1996).

81 See V Deloria Jr and CM Lytle, The Nations Within: The Past and Future of American Indian Sovereignty (Pantheon Books, 1984); DE Wilkins and KT Lomawaima, Uneven Ground: American Indian Sovereignty and Federal Law (University of Oklahoma Press, 2001); C Wilkinson, Blood Struggle: The Rise of Modern Indian Nations (WW Norton, 2005); NB Duthu, American Indians and the Law (Viking Penguin, 2008).

82 See US v Shoshone Tribe, 304 US 111, 115-18 (1938); US v Klamath and Moadoc Tribes, 304 US 119, 122-23 (1938); Otoe and Missouria Tribe v US, 131 F Supp 265, $290-91$ (1955), cert denied 350 US 848 (1955); US v Northern Paiute Nation, 393 F 2d 786, 796 (1968); US ex rel Chunie v Ringrose, 788 F 2d 638, 642 (1986).

83 However, from 1887 to 1934, the General Allotment Act, 24 US Stat 388, allowed for creation and sale of individual allotments and distribution of 'surplus' Indian land to homesteaders: see DS Otis, The Dawes Act and the Allotment of Indian Land, edited by FP Prucha (University of Oklahoma Press, 1973); FP Prucha, American Indian Policy in Crisis: Christian Reformers and the Indian, 1865-1900 (University of Oklahoma Press, 1976) 227-64; CF Wilkinson, American Indians, Time, and the Law: Native Societies in a Modern Constitutional Democracy (Yale University Press, 1987) 8-9, 19-20; and Benjamin J Richardson's chapter on US Indian Law. 
United States, ${ }^{84}$ the Court held that Indian title that has not been legislatively or executively recognized by the United States is not a property right compensable under the Fifth Amendment to the American Constitution. ${ }^{85}$ Instead, it is a mere 'right of occupancy [that] may be terminated and such lands fully disposed of by the sovereign itself [the United States] without any legally enforceable obligation to compensate the Indians ${ }^{96}$ Although this decision has been justifiably criticized, ${ }^{87}$ the jurisdictional dimensions of Indian title and the political nature of the relationship between the Indian nations and the United States may help to explain it. ${ }^{88}$ Justice Reed, in his majority judgment, remarked that the TeeHit-Ton claim 'was more a claim of sovereignty than of ownership'. ${ }^{89}$ As discussed in the introduction to this chapter, sovereignty is distinct from property, and numerous decisions of the Supreme Court have held that Indian sovereignty is subject to the plenary power of Congress. ${ }^{90}$ Nonetheless, it is more in keeping with the territorial nature of Indian rights, and with earlier American case law, to regard these rights as both jurisdictional and proprietary. ${ }^{91}$

84
348 US 272 (1955).

1 US Stat 21. The Fifth Amendment provides, among other things, that private property shall not be taken for public use without just compensation.

Tee-Hit-Ton Indians, above n 84, 279.

Eg see JY Henderson, 'Unraveling the Riddle of Indian Title' (1977) 5 American Indian Law Review 75; NJ Newton, 'At the Whim of the Sovereign: Aboriginal Title Reconsidered' (1980) 31 Hastings Law Journal 1215; SJ Bloxham, 'Aboriginal Title, Alaskan Native Property Rights, and the Case of the Tee-Hit-Ton Indians' (1980) 8 American Indian Law Review 299.

See McNeil, above n 15, 259-67. For a political analysis of the decision, see K McNeil, 'How the New Deal Became a Raw Deal for Native Americans: The Tee-Hit-Ton Alaska Decision and the Denial of Fifth Amendment Protection to Indian Land Title', paper delivered at the Western History Association's 40th Annual Conference, San Antonio, Texas, October 11-14, 2000 (on file with author).

Tee-Hit-Ton Indians, above n 84, 287.

Eg see Lone Wolf v Hitchcock, 187 US 553 (1903); US v Wheeler, 435 US 313, 323 (1978); Cotton Petroleum Corporation v New Mexico, 490 US 163, 192 (1989); South Dakota v Yankton Sioux Tribe, 522 US 329, 343 (1998). For critical commentary, see V Deloria Jr, Behind the Trail of Broken Treaties: An Indian Declaration of Independence (University of Texas Press, 1985) 141-60; Wilkins and Lomawaima, above $\mathrm{n} 81,98-116$. See also the concurring judgment of Thomas $\mathrm{J}$ in Lara, above n 4, questioning the plenary power doctrine.

See text accompanying n 35-40 above. 
In Australia, reliance on traditional laws and customs and the doctrine of continuity has had a very negative impact on Indigenous land rights. ${ }^{92}$ Contrary to the all-encompassing native title of the Miriam People declared by the High Court in Mabo, in subsequent cases Indigenous claimants have had to prove rights in relation to land by reference to specific laws and customs at the time of Crown acquisition of sovereignty. The content of their rights is therefore defined by their laws and customs. ${ }^{93}$ So even if they were in exclusive occupation of land at that time, they would not, for example, have any rights to minerals if they did not have laws and customs in relation to those resources. ${ }^{94}$

Post-Mabo, the High Court has thus taken a particularized approach to native title, treating it as a divisible bundle of rights, each arising from specific laws or customs. As a result, a right to take estuarine crocodiles is as much a native title right as a right to exclusive possession. ${ }^{95}$ So Australian law contains no equivalent to the fundamental Canadian distinction between Aboriginal title and other Aboriginal land rights. Moreover, the High Court has adamantly refused to envisage continuation of rights other than in relation to land. The doctrine of continuity has therefore been applied selectively, eliminating the possibility of an Indigenous right of self-government. ${ }^{96}$ On the positive side, this means that native title rights and interests can co-exist with nonexclusive third party interests, such as some pastoral leaseholds, though in the event of conflict the third party interests generally prevail. ${ }^{97}$

While the doctrine of continuity has also been applied in New Zealand, it has not had the negative impact seen in Australia. This is mainly because Māori land rights are based on tikanga Māori, encompassing both custom and usage. ${ }^{98}$ Rights that were not otherwise

92 For detailed discussion, see McNeil, above n 48; Strelein, above n 50; Young, above n 50 .

$93 \quad$ See esp Ward and Yorta Yorta, above n 50.

$94 \quad$ Ward, above n 50, esp para 382.

$95 \quad$ Yanner $v$ Eaton (1999) 166 ALR 258 (HC Aust).

$96 \quad$ See Walker $v$ New South Wales (1994) 182 CLR 45; Coe v Commonwealth (1993), 68 ALJR 110; Thorpe v Commonwealth [No 3] (1997) 71 ALJR 767; Yorta Yorta, above n 50.

97 See Wik Peoples v Queensland (1996) 141 ALR 129 (HC Aust); K McNeil, 'CoExistence of Indigenous Rights and Other Interests in Land in Australia and Canada' [1997] 3 Canadian Native Law Reporter 1. Compare Anderson v Wilson (2002) 213 CLR 401 (HC Aust).

$98 \quad$ See text accompanying n 57-58 above. 
extinguished have mostly been converted into common law interests by the Native Land Court (now the Māori Land Court). ${ }^{99}$ But as recently affirmed by the NZ Court of Appeal, Māori land rights based on tikanga Māori can still exist, usually as exclusive interests equivalent to fee simple estates, or, less commonly, as more limited interests. ${ }^{100}$ Although the matter has not yet been conclusively decided, it appears that exclusive Māori interests include rights to standing timber and mineral resources, a conclusion that follows from their equivalence to fee simple. ${ }^{101}$

\section{Proof Of Indigenous LAND Rights}

When Indigenous peoples seek judicial acknowledgment of their land rights in the courts of the nation-states that have asserted sovereignty over them, they have the onus of proving their rights in accordance with tests and standards that are usually set by the judiciary. ${ }^{102}$ These tests and standards vary from one jurisdiction to another, depending on the source of the title and other factors, but the burden of proof is always onerous. The difficulties Indigenous claimants face are compounded by the fact that their traditions were generally oral, and courts tend to place greater weight on written documents in determining historical issues arising beyond the limits of living memory.

The Supreme Court of Canada has acknowledged these difficulties, and has sought to alleviate them to some extent by directing trial judges to admit oral histories as evidence and to accord them appropriate weight. In Delgamuukw, for example, the Court overturned the trial judge's decision and ordered a new trial, in part because he had not given sufficient credence or weight to the oral histories of the Gitksan and Wet'suwet'en

99 See DV Williams, 'Te Kooti Tango Whenua': The Native Land Court 18641909 (Huia Publishers, 1999), and Jacinta Ruru's chapter.

100 See Ngati Apa, above n 10, esp per Elias CJ, para 46; Young, above n 50, 167200.

101 See New Zealand Maori Council v Attorney-General [1989] 2 NZLR 142 (CA); Tainui Maori Trust Board v Attorney-General [1989] 2 NZLR 513 (CA), per Cooke P, 527-30; and discussion in Young, above n 50, 180-82.

102 For critical analysis in the Canadian context, see K McNeil, 'The Onus of Proof of Aboriginal Title' (1999) 37 Osgoode Hall Law Journal 775, reprinted in Emerging Justice?, above n 41, 136. 
claimants. After acknowledging that the hearsay rule, for example, could act as a barrier to the use of oral histories in court, Chief Justice Lamer stated that 'the laws of evidence must be adapted in order that this type of evidence can be accommodated and placed on an equal footing with the types of historical evidence that courts are familiar with, which largely consists of historical documents'. ${ }^{103}$ Nonetheless, judges still retain considerable discretion regarding the weight to be given to any evidence, including oral histories. ${ }^{104}$ Moreover, in Australia there appears to be an on-going tendency to give more weight to the written evidence of settlers than to the oral histories of Indigenous peoples. ${ }^{105}$

What Indigenous peoples actually have to prove to establish their land rights depends largely on the source of these rights. In Canada, where Aboriginal title is based on occupation, Aboriginal peoples have to prove that they were in exclusive occupation of the claimed land at the time of British assertion of sovereignty. ${ }^{106}$ As discussed earlier, the requisite occupation can be established by proof of physical presence and use of the land, and by evidence of Aboriginal law. In Delgamuukw, Chief Justice Lamer explained:

... the source of aboriginal title appears to be grounded both

in the common law and in the aboriginal perspective on

land; the latter includes, but is not limited to, their systems

103 Delgamuukw, above n 10, para 87. See also Van der Peet, above n 30, para 68; Mitchell, above n 41, para 27-39; Benoit v Canada [2003] 3 CNLR 20 (FCA), leave to appeal refused, SCC, 29 April 2004. For discussion, see J Borrows, 'Listening for a Change: The Courts and Oral Traditions' (2001) 39 Osgoode Hall Law Journal 1.

$104 \quad$ Mitchell, above n 41, para 36.

105 Eg see Members of the Yorta Yorta Aboriginal Community v Victoria [1998] FCA 1606, aff'd [2001] 110 FCR 244, (2002) 214 CLR 422. Compare De Rose $v$ South Australia [No 1] [2002] FCA 1342, rev'd on other grounds (2003) 133 FCR 325 (Full FC), and Neowarra v Western Australia [2003] FCA 1402, where oral histories figured more prominently. In the United States, the Indian Claims Commission, though given a broad mandate that included authority to hear and determine 'claims based upon fair and honorable dealings that are not recognized by any existing rule of law or equity' (Indian Claims Commission Act of 1946, 60 Stat 1049, s 2: see Michael Coyle's chapter), generally regarded oral histories as too vague and self-serving to be relied upon: eg see Pueblo of Taos $v$ US, 15 ICC 688, 694-95 (1965). For commentary, see G Stohr, 'The Repercussions of Orality in Federal Indian Law' (1999) 31 Arizona State Law Journal 679.

106 Delgamuukw, above n 10, para 144. 
of law. It follows that both should be taken into account in establishing the proof of occupancy. ${ }^{107}$

Regarding physical occupation, Lamer CJ said it "may be established in a variety of ways, ranging from the construction of dwellings through cultivation and enclosure of fields to regular use of definite tracts of land for hunting, fishing or otherwise exploiting its resources'. ${ }^{108}$ Factors to consider in deciding whether the occupation was sufficient to establish title include 'the group's size, manner of life, material resources, and technological abilities, and the character of the lands claimed'. ${ }^{109}$

Somewhat surprisingly, when the Supreme Court next considered proof of Aboriginal title in $R v$ Marshall; $R v$ Bernard, ${ }^{110}$ Chief Justice McLachlin emphasized the importance of physical occupation, and virtually ignored the evidentiary role of Aboriginal law. She also seems to have raised the threshold for establishing occupation by deciding that proof of occupation of specific sites rather than of a broader territory is required. ${ }^{111}$ She suggested as well that nomadic peoples may not have been in sufficient occupation of at least some of their territories to have title. In contrast, Justice LeBel (Fish J concurring), in a separate judgment concurring in result, thought the Chief Justice's physical occupation approach was 'too narrowly focused on common law concepts relating to property interests', and might preclude establishment of Aboriginal title by nomadic or semi-nomadic peoples. ${ }^{112}$ Moreover, in his trial decision in the Tsilhqot'in Nation case in 2007, Justice Vickers of the BC Supreme Court found that Marshall and Bernard differed from the claim before him because in that case 'the persons accused both attempted to prove Aboriginal title at specific sites' to defend themselves against charges of violations of provincial forestry legislation, ${ }^{113}$ whereas in the Tsilhqot'in

$107 \quad$ Ibid, para 147.

Ibid, para 149 .

Ibid, quoting B Slattery, 'Understanding Aboriginal Rights' (1987) 66 Canadian Bar Review 727, 758.

110 Above n 26. For critical commentary, see K McNeil, 'Aboriginal Title and the Supreme Court: What's Happening?’ (2006) 69 Saskatchewan Law Review 281.

111 Compare the more territorial approach taken by Cromwell JA of the NSCA and Daigle JA of the NBCA: $R v$ Marshall (2003) 218 NSR (2d) 78, esp para 183; $R$ $v$ Bernard (2003) 262 NBR (2d) 1, esp para 85.

Marshall and Bernard, above n 26, para 110, 126.

In Marshall and Bernard, ibid, para 142-43, LeBel J also expressed reservations over deciding Aboriginal title in a quasi-criminal prosecution. See S Imai, 'The 
claim for a declaration of Aboriginal title the evidence ranged 'over tracts of land'. ${ }^{114}$

Marshall and Bernard also addressed the requirement that the occupation be exclusive. After noting that factual evidence of acts of exclusion might not be available, Chief Justice McLachlin concluded that evidence of acts of exclusion is not required to establish aboriginal title. All that is required is demonstration of effective control of the land by the group, from which a reasonable inference can be drawn that it could have excluded others had it chosen to do so. ${ }^{115}$

In connection with exclusivity, in Delgamuukw the Court briefly addressed another issue, namely, whether two or more Aboriginal groups can have joint title if they occupied land to the exclusion of other Aboriginal groups. Chief Justice Lamer suggested that shared exclusivity could result in joint Aboriginal title, ${ }^{116}$ as recognized by the US Supreme Court in United States $v$ Santa Fe Pacific Railroad. ${ }^{117}$ While this issue has not, as far as I know, received further judicial consideration in Canada, several American decisions have acknowledged that joint title can exist where two or more Indian nations amicably occupied land to the exclusion of other Indian nations. ${ }^{118}$

As discussed earlier, Canadian law distinguishes between Aboriginal title and other land rights, which generally involve rights to harvest particular resources from specific lands. Proof of the latter involves meeting the test created by the Supreme Court in the Van der

Adjudication of Historical Evidence: A Comment and an Elaboration on a Proposal by Justice LeBel' (2006) 55 University of New Brunswick Law Journal 146.

Tsilhqot'in Nation, above n 26, para 582.

Marshall and Bernard, above n 26, para 65.

Delgamuukw, above n 10, para 158.

314 US 339 (1941).

See Iowa Tribe of the Iowa Reservation v US, 195 Ct Cl 365, $394-96$ (1971); Turtle Mountain Band of Chippewa Indians v US, 490 F 2d 935, 944 (1974, Ct Cl); US v Pueblo of San Ildefonso, 513 F 2d 1383, 1394-95 (1975, Ct Cl); Strong $v$ US, 518 F 2d 556, 561-62 (1975, Ct Cl), cert denied 423 US 1015 (1975); Uintah Ute Indians v US, $28 \mathrm{Fed} \mathrm{Cl} \mathrm{768,} \mathrm{785,} 787$ n 21 (1993). For discussion, see MJ Kaplan, 'Proof and Extinguishment of Aboriginal Title to Indian Lands' (1979, updated 2003) LEXSEE 41 ALR Fed 425, heading 3b, "'Exclusive" use or occupancy; joint aboriginal title'. 
Peet decision: Aboriginal claimants must show that the activity they claim a right over was 'an element of a practice, custom or tradition integral to [their] distinctive culture' at the time of European contact $^{119}$ or, for the Métis, effective European control. ${ }^{120}$ Applying this test in 2006 in Sappier and Gray, Justice Bastarache said that '[f]lexibility is important when engaging in the Van der Peet analysis because the object is to provide cultural security and continuity for the particular aboriginal society'. ${ }^{121}$ Regarding the 'integral to the distinctive culture' aspect of the test, he clarified:

What is meant by 'culture' is really an inquiry into the precontact way of life of a particular aboriginal community, including their means of survival, their socialization methods, their legal systems, and, potentially, their trading habits. The use of the word 'distinctive' as a qualifier is meant to incorporate an element of aboriginal specificity. However, 'distinctive' does not mean 'distinct', and the notion of aboriginality must not be reduced to 'racialized stereotypes of Aboriginal peoples'. ${ }^{122}$

On the basis of the evidence presented, the Supreme Court accordingly held that the Pabineau and Woodstock First Nations of the Mi'kmaq and Maliseet peoples have an Aboriginal right to harvest wood for domestic uses on Crown lands traditionally used by them for that purpose.

In the United States, there is no equivalent to the distinction between Indian title and other Indian land rights found in Aboriginal rights law in Canada. ${ }^{123}$ The explanation appears to be that American courts have defined occupation more broadly, so that virtually any Indian use of lands can give rise to Aboriginal or Indian title. ${ }^{124}$ As early as 1835, Justice Baldwin expressed the opinion of the Supreme Court that Indian

$119 \quad$ Van der Peet, above n 30, para 46, 73.

$120 \quad$ Powley, above n 31.

$121 \quad$ Sappier and Gray, above n 29, para 33.

122 Ibid, para 45, quoting J Borrows and LI Rotman, 'The Sui Generis Nature of Aboriginal Rights: Does it Make a Difference?’ (1997) 36 Alberta Law Review 9,36 .

123 While Indian resource rights can exist off their lands in the United States, this is usually the result of treaties: see Duthu, above n 81, 99-109.

124 See FS Cohen, 'Original Indian Title' (1947) 32 Minnesota Law Review 28. 
occupation 'was considered with reference to their habits and modes of life; their hunting-grounds were as much in their actual possession as the cleared fields of the whites, and their rights to its exclusive enjoyment in their own way and for their own purposes were as much respected'. ${ }^{125}$ So while Indian title, like Aboriginal title in Canada, is based on exclusive occupation, American courts have taken a distinctly territorial approach to its geographical extent. In Santa Fe Pacific Railroad, Justice Douglas said:

If it were established as a fact that the lands in question were, or were included in, the ancestral home of the Walapais in the sense that they constituted definable territory occupied exclusively by the Walapais (as distinguished from lands wandered over by many tribes), then the Walapais had 'Indian title'. ${ }^{126}$

The same territorial approach has been taken in other American cases, including decisions of the Court of Claims on appeals from the Indian Claims Commission, which had been established in 1946 to resolve outstanding Indian claims against the US government. ${ }^{127}$ Even tribes described as 'nomadic' have been held to have Indian title to lands they used on a regular basis in accordance were their own ways of life. ${ }^{128}$ Moreover, title extends to 'seasonal or hunting areas over which the Indians had control even though those areas were only used intermittently'. ${ }^{129}$

Another important distinction between Canadian and American law in relation to proof is that Indian claimants in the United States do not have to prove occupation of land at the time of British, or even American,

\footnotetext{
$125 \quad$ Mitchel $v$ US, 34 US (9 Pet) 711, 746 (1835).

126 Santa Fe Pacific Railroad, above n 117, 345.

127 See I Sutton (ed), Irredeemable America: The Indians' Estate and Land Claims (University of New Mexico Press, 1985), and Michael Coyle's chapter.

128 US v Kagama, 118 US 375, 381 (1886); Cramer v US, 261 US 219, 227 (1923); Northwestern Bands of Shoshone Indians v US, 324 US 335, 338-40 (1945); Tee-Hit-Ton Indians v US, 120 F Supp 202, 204 (1954, Ct Cl), aff'd above n 84, 285-88.

129 Confederated Tribes of the Warm Springs Reservation of Oregon $v$ US, $177 \mathrm{Ct}$ $\mathrm{Cl}$ 184, 194 (1966). See also Delaware Tribe of Indians v US, $130 \mathrm{Ct} \mathrm{Cl} \mathrm{782,}$ 789 (1955); Spokane Tribe v US, $163 \mathrm{Ct} \mathrm{Cl} \mathrm{58,} 66$ (1963).
} 
assertion of sovereignty. Instead, proof of occupation 'for a long time' is sufficient. ${ }^{130}$ In Confederated Tribes of the Warm Springs Reservation of Oregon v United States, Justice Durfee explained:

The time requirement, as a general rule, cannot be fixed at a specific number of years. It must be long enough to have allowed the Indians to transform the area into domestic territory [so that the court is not] 'creating aboriginal title in a tribe which itself played the role of conqueror but a few years before'. ${ }^{131}$

This means that Indian nations could acquire title from one another (especially if by peaceful transfer) or by occupying vacant lands after American assertion of sovereignty, ${ }^{132}$ and eases the burden of proof by shortening the timeframe for establishing the requisite occupation. ${ }^{133}$

Finally, while American courts have held that the occupation required for Indian title is a matter of fact, ${ }^{134}$ what has to be established is not so much physical occupation as control of territory. In United States $v$ Seminole Indians of Florida, Justice Collins said that

the Government leans far too heavily in the direction of equating 'occupancy' (or capacity to occupy) with actual possession, whereas the key to Indian title lies in evaluating the manner of land-use over a period of time. Physical

$130 \quad$ Sac and Fox Tribe of Indians of Oklahoma $v$ US, $161 \mathrm{Ct} \mathrm{Cl} \mathrm{189,} \mathrm{202,} \mathrm{205-7}$ (1963), cert denied 375 US 921 (1963); Confederated Tribes of the Warm Springs Reservation, above n 129, 194; US v Pueblo of San Ildefonso, above $\mathrm{n}$ 118, 1394; Seneca Nation of Indians v New York, 206 F Supp 2d 448, 503 (2002, WDNY).

131 Confederated Tribes of the Warm Springs Reservation, above n 129, 194. quoting Sac and Fox Tribe, above n 130, 206.

$132 \quad$ Turtle Mountain Band of Chippewa Indians, above n 118.

133 In US v Seminole Indians of Florida, $180 \mathrm{Ct}$ Cl 375 (1967), 58 years was held to be a sufficiently long time to acquire title. In Alabama-Coushatta Tribe v US, 28 Fed Cl 95 (1993), 30 years sufficed.

134 See Santa Fe Pacific Railroad, above n 117, 345, quoted in text accompanying n 126 above; Pueblo of San Ildefonso, above n 118, 1394; Six Nations v US, 173 $\mathrm{Ct} \mathrm{Cl} 899$ at 910 (1965). 
control or dominion over the land is the dispositive criterion. $^{135}$

Proof of native title in Australia is another matter entirely. What is required is not evidence of exclusive occupation or control, but rather of a connection to the land through traditional laws and customs. ${ }^{136}$ This requirement originated from Justice Brennan's judgment in Mabo. ${ }^{137}$ As we have seen, it was given statutory force by incorporation into the definition of native title in section 223(1) of the Native Title Act 1993, ${ }^{138}$ which, as interpreted by the High Court, makes it necessary for claimants to prove that they have maintained a connection with the land through substantially uninterrupted acknowledgement and observance of their laws and customs from the time of Crown assertion of sovereignty to the present. ${ }^{139}$ This requirement make proof of native title especially difficult for Indigenous peoples in more populated areas whose connection to the land and observance of traditional laws and customs have been severely interfered with by settlers. Particularly disturbing is the pronouncement by the Full Federal Court in 2008 that the cause of loss of connection and observance is irrelevant. ${ }^{140}$ Apparently, even illegal squatting - a historically common way of taking Indigenous land in Australia - could have resulted in loss of native title because it would have severed the necessary connection with the land.

The Australian High Court's approach to native title claims also necessitates proof of specific laws and customs relating to particular uses of lands and resources. ${ }^{141}$ It is not enough for claimants to establish they had, and have maintained, a general system of traditional laws and

\footnotetext{
135 Seminole Indians of Florida, above n 133, 385-86 (emphasis in original).

136 See Ward, above n 50, esp para 89-93.

137 Mabo, above n 11, esp 58-60.

138 See text accompanying n 49-50 above.

139 Yorta Yorta, above n 50. See also De Rose [No 1], above n 105 (Full FC); De Rose v South Australia [No 2] (2005) 145 FCR 290; Northern Territory v Alyawarr (2005) 145 FCR 442; Bodney v Bennell [2008] FCAFC 63.

140 Bodney $v$ Bennell, above n 139, para 96-97, relying on Yorta Yorta, above n 50, para 89-90.

141 See esp Ward, above n 50. For application of the High Court's approach, see Daniel v Western Australia [2003] FCA 666; Sampi v Western Australia [2005] FCA 777; Rubibi Community (No 7) v Western Australia [2006] FCA 459; Risk $v$ Northern Territory [2006] FCA 404, aff'd (2007) 240 ALR 75 (Full FC). Compare Neowarra, above n 105.
} 
customs in relation to land; instead, they have to prove that their laws and customs provide specific 'rights' that are recognizable as such by common law courts. ${ }^{142}$ So, unlike in Canada where historical practices alone can generate rights, Australian law requires proof that practices were engaged in pursuant to traditional laws and customs. ${ }^{143}$ Moreover, as mentioned previously, in Australia proof of exclusive occupation does not necessarily result in all-inclusive rights to surface and subsurface resources. ${ }^{144}$

While New Zealand has also based Māori land rights on preexisting laws and customs, this has not had the negative consequences that reliance on traditional laws and customs has had in Australia. This is because Māori land rights are more broadly grounded in tikanga Māori, which includes both custom and usage. ${ }^{145}$ Proof of Māori land rights therefore involves proof of custom or usage in relation to the claimed land at the time of British assertion of sovereignty in 1840. If the claimant group proves exclusive occupation, they have title equivalent to an inalienable fee simple estate, whereas proof of customary rights or uses not amounting to exclusive occupation could result in more limited interests. ${ }^{146}$ Moreover, unlike in Australia, it does not appear to be necessary in New Zealand to prove continuous observance of tikanga Māori from the time of British assertion of sovereignty to the present. ${ }^{147}$ As in Canada, where title has been established as of that time, apparently it is presumed to continue until shown to have been extinguished. ${ }^{148}$

For detailed discussion and criticism, see Young, above n 50.

See Mason v Tritton (1994) 34 NSWLR 572 (NSWCA); Derschaw v Sutton (1996) 90 A Crim R 9 (Full SCWA); Dillon v Davies (1998) 156 ALR 142 (SC Tas). For discussion, see McNeil, above n 48, 454-58; Dorsett, above n 50 at 6166; Young, above n 50, 338-42; A Erueti, 'The Recognition of Indigenous Peoples' Rights to Traditional Lands: The Evaluation of States by International Treaty Bodies' in Charters and Erueti, above n 50, 175, 178-83.

Ward, above n 50, esp para 382 .

This is a statutory as well as common law approach: Kauwaeranga Judgment, Native Land Court, 1870, reproduced (1984) 14 Victoria University of Wellington Law Review 227; Ngati Apa, above n 10. See Jacinta Ruru's chapter. See text accompanying n 98-101 above.

See Young, above n 50, 172-75.

See K McNeil, 'Continuity of Aboriginal Rights', in Wilkins, above n 14, 127. However, the New Zealand Foreshore and Seabed Act 2004, s 50(1)(b), created a statutory exception: see McNeil, above n 58, 92-93, 103-16; Dorsett, above $n$ 50, 74-77; Erueti, above n 143, 186-87. 


\section{EXTINGUISHMENT AND INFRINGEMENT OF INDIGENOUS LAND RIGHTS}

In all four jurisdictions considered in this chapter, Indigenous land rights can be voluntarily surrendered by means of a treaty or other agreement. In British North America, this was specified in the Royal Proclamation of 1763, which forbid private acquisition of Indian lands and stipulated that they could only be acquired by the Crown or a proprietary government at a public assembly of the Indian titleholders gathered for that purpose ${ }^{149}$ The Proclamation continued the pre-existing Crown practice of purchasing Indian lands, resulting in land-surrender treaties in what is now Canada from 1763 to the 1920s, when the Canadian government stopped negotiating treaties. The process recommenced in the 1970s when, following the Supreme Court of Canada's acknowledgment of the existence of Aboriginal title in Calder, ${ }^{150}$ Canada established the comprehensive claims process. ${ }^{151}$ In the 1990 s, a similar process was created in British Columbia when the BC Treaty Commission was set up to facilitate the negotiation of land claims in that province. ${ }^{152}$

Extinguishment of Aboriginal title by treaty or other agreement is controversial. Regarding the Canadian historical treaties, questions remain regarding interpretation of the land-surrender provisions, and what the Aboriginal parties understood those provisions to mean. ${ }^{153}$ In the Prairie Provinces, for example, it has often been contended that the land was to be shared, and that only surface rights to the depth of a plow were being

\footnotetext{
149 See Mark Walters' chapter.

150 Above $\mathrm{n} 20$.

151 See Michael Coyle's chapter.

152 See C McKee, Treaty Talks in British Columbia: Negotiating a Mutually Beneficial Future (UBC Press, 1996); A Woolford, Between Justice and Certainty: Treaty Making in British Columbia (UBC Press, 2005); T Penikett, Reconciliation: First Nations Treaty Making in British Columbia (Douglas and McIntyre, 2006).

153 See Re Paulette (1973) 42 DLR (3d) 8 (NWTSC), rev'd on other grounds (1975) 63 DLR (3d) 1 (NWTCA), [1977] 2 SCR 628; P Macklem, 'The Impact of Treaty 9 on Natural Resource Development in Northern Ontario' in Asch, above n 23, 97; S Imai, "Treaty Lands and Crown Obligations: The "Tracts Taken Up" Provision' (2001) 27 Queen's Law Journal 1.
} 
accorded to the government for the purpose of farming. ${ }^{154}$ Questions have also been raised over whether Aboriginal peoples had the authority under their own systems of law to alienate their lands. ${ }^{155}$ In the modern-day treaty process, extinguishment of rights has been vigorously opposed by Aboriginal peoples, and compromises have been sought to affirm existing rights while meeting government demands for certainty. ${ }^{156}$

In the United States, the federal government continued the British policy of acquiring Indian lands by purchase, though often by applying coercion, especially during the $19^{\text {th }}$ century removal period when many eastern tribes were moved from their homelands to Indian Territory in what later became the State of Oklahoma. ${ }^{157}$ Congress also has the authority to extinguish or infringe Indian title unilaterally, without any legal obligation to pay compensation unless the United States had previously recognized the title by treaty, agreement or unilateral government action. ${ }^{158}$ The states, however, have no such authority, as the Commerce Clause in the American Constitution gives Congress exclusive jurisdiction over Indian affairs, and the Indian Trade and Intercourse Acts, dating from the 1790 s, prohibit state acquisition of Indian lands. ${ }^{159}$ In the

$154 \quad$ See Treaty 7 Elders et al, The True Spirit and Original Intent of Treaty 7 (McGill-Queen's University Press, 1996) esp 113-23, 144-45; H Cardinal and W Hildebrandt, Treaty Elders of Saskatchewan: Our Dream Is That Our Peoples Will One Day Be Clearly Recognized as Nations (University of Calgary Press, 2000) esp 34-47.

155 See L Little Bear, "Aboriginal Rights and the Canadian "Grundnorm" in JR Ponting (ed), Arduous Journey: Canadian Indians and Decolonization (McClelland and Stewart, 1986) 243, 247; Canada, Report of the Royal Commission on Aboriginal Peoples, vol 2, Restructuring the Relationship (Supply and Services Canada, 1996) 459; S Venne, 'Understanding Treaty 6: An Indigenous Perspective' in Asch, above n 23, 173, esp 192-93.

156 See Report of the Royal Commission on Aboriginal Peoples, vol 2, above n 155 , 527-57; M Asch and N Zlotkin, 'Affirming Aboriginal Title: A New Basis for Comprehensive Claims Negotiations' in Asch, above n 23, 208; and works cited in $\mathrm{n} 152$ above.

157 See FP Prucha, American Indian Policy in the Formative Years (Harvard University Press, 1962); RN Satz, American Indian Policy in the Jacksonian Era (University of Oklahoma Press, 1975); MD Green, The Politics of Indian Removal: Creek Government and Society in Crisis (University of Nebraska Press, 1982). Tee-Hit-Ton Indians, above n 84. See also Kaplan, above n 118, heading III, 'Extinguishing aboriginal title'.

159 Originally 1 US Stat 137 (1790). See County of Oneida v Oneida Indian Nation, 470 US 226 (1985); RN Clinton and MT Hotopp, 'Judicial Enforcement of the 
past, the United States could also extinguish Indian title by conquest, ${ }^{160}$ though more commonly military force was used to compel Indian tribes to cede their lands to the government. ${ }^{161}$

In theory, British common law restrictions on the authority of the Crown would have prevented the taking of Indigenous lands by conquest in Canada, Australia and New Zealand after Crown acquisition of sovereignty. In practice, however, legal constraints are not always effective: in Australia, Aboriginal peoples were often killed or driven from their lands by force, whereas in New Zealand the wars of the 1860s resulted in substantial loss of life and land. ${ }^{162}$ Because Indigenous land rights were not acknowledged (apart from statute) in Australia prior to the Mabo decision in 1992, ${ }^{163}$ no recognized land-surrender treaties or agreements were entered into there. The Treaty of Waitangi in New Zealand confirmed rather than extinguished Māori land rights, though large areas of Māori land have been lost through conversion of those rights to common law interests and subsequent alienations. ${ }^{164}$

In the absence of constitutional protections for Indigenous land rights, there are no domestic legal impediments to extinguishment or infringement of those rights by legislatures that have constitutional authority over them. ${ }^{165}$ Legislative extinguishment has occurred relatively recently in Australia and New Zealand. By the Native Title Act 1993 (as amended), ${ }^{166}$ the Australian Parliament validated some past acts, such as

Federal Restraints on Alienation of Indian Land: The Origins of the Eastern Land Claims' (1979) 31 Maine Law Review 17; GC Shattuck, The Oneida Land Claims: A Legal History (Syracuse University Press, 1991). See Johnson, above n 35, 586-92; Santa Fe Pacific Railroad, above n 117, 347. See generally S Banner, How the Indians Lost Their Land: Law and Power on the Frontier (Belknap Press of Harvard University Press, 2005).

See H Reynolds, The Other Side of the Frontier: Aboriginal Resistance to the European Invasion of Australia (Penguin Books, 1982); D Day, Claiming a Continent: A New History of Australia (HarperCollins, 2001) 73-88; J Belich, The New Zealand Wars and the Victorian Interpretation of Racial Conflict (Auckland University Press, 1987); M King, The Pelican History of New Zealand (Penguin Books, 2003), 211-24.

Above $\mathrm{n} 11$.

See Orange, above n 9, 80-85; McHugh, above n 9, 333-34.

See K McNeil, 'Extinguishment of Aboriginal Title in Canada: Treaties, Legislation and Judicial Discretion' (2001-2002) 33 Ottawa Law Review 301, esp 317-27.

Above $\mathrm{n} 49$. 
Crown grants of land, so that they extinguished or infringed native title rights. ${ }^{167}$ In 2004, the New Zealand Parliament enacted the Foreshore and Seabed Act, extinguishing most Māori rights to coastal lands below the high-water mark. ${ }^{168}$

It is, however, essential to distinguish between legislative and executive authority. In parliamentary systems of government established on the British model, the executive branch of government has no authority apart from statute to take away or infringe property rights. ${ }^{169}$ As Indigenous land rights in Canada, Australia and New Zealand are proprietary, it should be unconstitutional for the executive branch to extinguish or infringe them without clear and plain statutory authority. While this appears to be the law in Canada and New Zealand, ${ }^{170}$ in Australia the High Court has held that, prior to enactment of the Racial Discrimination Act 1975 (Cth), ${ }^{171}$ native title could be extinguished executively by inconsistent Crown grant or Crown appropriation of the land for its own use, apparently without clear and plain statutory authority to do so. ${ }^{172}$ Moreover, no compensation needed to be paid for this

\footnotetext{
167 See McRae, above n 44, 341-45; Bartlett, above n 49, 392-402. However, s 51(xxxi) of the Australian Constitution (s 9 of the Commonwealth of Australia Constitution Act, 63 and 64 Vict, c 12 (UK)), provides that the taking of property by Parliament be on 'just terms', and so the Native Title Act 1993 provides for compensation: McRae, 356-57; Bartlett, 402.

168 See Charters and Erueti, above n 50

$169 \quad$ Entick v Carrington (1765) 19 St Tr 1030 (CP); Attorney-General v De Keyser's Royal Hotel [1920] AC 508, 569 (HL); Spooner Oils Ltd v Turner Valley Gas Conservation Board [1933] SCR 629. See JW Ely Jr, The Guardian of Every Other Right: A Constitutional History of Property Rights (2nd ed, Oxford University Press, 1998) 13-14, 54-55.

170 Re Canada, see Calder, above n 20, 402 (Hall J, dissenting on the deciding issue); Guerin v The Queen [1984] 2 SCR 335, 376; $R$ v Sparrow [1990] 1 SCR 1075, 1099; Delgamuukw, above n 10, para 113, 180; and discussion in McNeil, above n 165, 311-16. Re New Zealand, see Nireaha Tamaki, above n 53.

171 This Act of Parliament provides legislative protection against discriminatory actions by the states that would extinguish native title rights: Mabo $v$ Queensland [No 1] (1988) 166 CLR 186 (HC Aust). The Native Title Act 1993 provides further protection because valid Commonwealth legislation prevails, due to s 109 of the Australian Constitution, above n 167, over inconsistent state legislation: Western Australia v Commonwealth (1995) 128 ALR 1 (HC Aust). See also Ward, above n 50.

172 Mabo, above n 11; Fejo, above n 50.
} 
unilateral taking. ${ }^{173}$ As both the taking and the denial of compensation are inconsistent with fundamental common law principles, ${ }^{174}$ it appears that the High Court was driven by political considerations to favour the property rights and economic interests of non-Indigenous Australians over the pre-existing land rights of the Indigenous peoples. ${ }^{175}$

In Canada, Aboriginal land rights have two additional constitutional protections that prevent even legislative extinguishment and infringement in some instances. First, section 91(24) of the Constitution Act, 1867, placed 'Indians, and Lands reserved for the Indians', within the exclusive jurisdiction of the Parliament of Canada. ${ }^{176}$ As a result, the Supreme Court has held that the provinces have lacked the constitutional authority to extinguish Aboriginal title ever since Confederation in $1867 .{ }^{177}$ While this should mean that the provinces also lack the authority to infringe Aboriginal title, ${ }^{178}$ the Supreme Court has suggested otherwise,

173 Mabo, above $\mathrm{n} \mathrm{11,15.} \mathrm{The} \mathrm{requirement} \mathrm{in} \mathrm{s} \mathrm{51(xxxi)} \mathrm{of} \mathrm{the} \mathrm{Australian}$ Constitution, above n 167, that taking of property be on 'just terms', applies only to Parliament, not to state legislatures, from the time the Constitution was proclaimed as of January 1, 1901.

174 See K McNeil, 'Racial Discrimination and Unilateral Extinguishment of Native Title' (1996) 1 Australian Indigenous Law Reporter 1, reprinted in Emerging Justice?, above n 41, 357. Extinguishment by grant is also inconsistent with American law, as a grantee in the United States generally takes subject to any unextinguished Indian title: see K McNeil, 'Extinguishment of Native Title: The High Court and American Law' (1997) 2 Australian Indigenous Law Reporter 365, reprinted in Emerging Justice?, above n 41, 409. Moreover, any Presidential taking of Indian land by executive order has to be authorized and ratified by Congress: Gila River Pima-Maricopa Indian Community v US, $494 \mathrm{~F}$ 2d 1386, 1394 (1974, Ct Cl), cert denied 419 US 1021 (1974).

175 See K McNeil, 'The Vulnerability of Indigenous Land Rights in Australia and Canada' (2004) 42 Osgoode Hall Law Journal 271.

176 Constitution Act, 1867, 30 and 31 Vict, c 3 (UK).

177 Delgamuukw, above n 10, para 172-83. Compare Australia, where Parliament first received jurisdiction over Indigenous affairs by a 1967 amendment to $\mathrm{s}$ 51(xxvi) of the Constitution, above n 167: see Jennifer Clarke's chapter. Because this jurisdiction is concurrent with state jurisdiction, the states are only barred from extinguishing native title to the extent that the extinguishment is inconsistent with federal legislation, such as the Native Title Act 1993: see n 171 above.

See Tsilhqot'in Nation, above n 26, para 1001-49; K McNeil, 'Aboriginal Title and the Division of Powers: Rethinking Federal and Provincial Jurisdiction' (1998) 61 Saskatchewan Law Review 431, reprinted in Emerging Justice?, above n 41, 249; K Wilkins, 'Of Provinces and Section 35 Rights' (1999) 22 
without adequately explaining how provincial legislatures can infringe rights that are within the core of the exclusive jurisdiction of Parliament. ${ }^{179}$ More recently, however, the Court has held that treaty rights, which are also within the core of Parliament's exclusive section 91(24) jurisdiction, are immune from provincial laws that would infringe them. ${ }^{180}$ Logically, Aboriginal title should have the same division-ofpowers protection. ${ }^{181}$

The second protection accorded to Aboriginal land rights in Canada is found in section 35(1) of the Constitution Act, 1982, which recognized and affirmed the 'existing aboriginal and treaty rights of the aboriginal peoples of Canada'. ${ }^{182}$ The Supreme Court has held that this provision prevents these rights from being unilaterally extinguished, even by Parliament. ${ }^{183}$ So, since 1982, extinguishment can only occur (constitutional amendment aside) with the consent of the Aboriginal peoples concerned. The Court has nonetheless held that, despite section 35(1), Aboriginal and treaty rights, including land rights, can still be infringed, provided the test for justifiable infringement laid down in Sparrow has been met. ${ }^{184}$ This test requires the government to prove two things: first, a valid legislative objective for the infringement that is substantial and compelling; and second, that the Crown's fiduciary obligations to the Aboriginal people in question have been respected. Depending on the circumstances, the second branch of the test can involve asking the following questions: "whether there has been as little infringement as possible in order to effect the desired result; whether, in a situation of expropriation, fair compensation is available; and, whether the aboriginal group in question has been consulted with respect to the

Dalhousie Law Journal 185 and 'Negative Capacity: Of Provinces and Lands Reserved for the Indians' (2002) 1 Indigenous Law Journal 57. See Côté, above n 29, para 74; Delgamuukw, above n 10, para 160.

$R v$ Morris [2006] 2 SCR 915. See K Wilkins, ' $R v$ Morris: A Shot in the Dark and Its Repercussions', forthcoming, Indigenous Law Journal. Doctrine of Interjurisdictional Immunity: A Commentary' in F Wilson and $\mathrm{M}$ Mallet (eds), Métis-Crown Relations: Rights, Identity, Jurisdiction, and Governance (Irwin Law, forthcoming).

Above $\mathrm{n} 31$.

Van der Peet, above n 30, para 28; Mitchell, above n 41, para 11. Sparrow, above n 170; $R$ v Gladstone [1996] 2 SCR 723; Côté, above n 29; Delgamuukw, above n 10; $R$ v Marshall [1999] 3 SCR 533; Sappier and Gray, above n 29. For critical commentary, see McNeil, above n 175, 286-300. 
conservation measures being implemented'. ${ }^{185}$ Since Sparrow, the consultation requirement has become a major factor in determining whether an infringement is justifiable. The Supreme Court has decided that governments must engage in consultation, and in appropriate situations accommodate Aboriginal interests, where Aboriginal rights, though not yet established, are asserted and supported by some evidence. ${ }^{186}$ The scope of the consultation depends on the strength of the case supporting the rights and the seriousness of the infringement. ${ }^{187}$

While government infringement of Aboriginal land rights is still possible in Canada, those rights nonetheless have much greater protection than Indigenous land rights in the United States, Australia and New Zealand. The addition of section 35(1) to the Canadian Constitution in 1982 took away the parliamentary equivalent of the plenary power that the US Congress still has over Indian tribes. Unilateral extinguishment has been barred, so that the kind of termination policy pursued by Congress in the 1950 s cannot occur in Canada. ${ }^{188}$ Nor can the Canadian Parliament enact provisions like those in the Native Title Act 1993 and the Foreshore and Seabed Act 2004 that have extinguished some land rights in Australia and New Zealand. Even parliamentary infringements of land rights have to be justified by a stringent test. The duty to consult and to accommodate asserted Aboriginal rights has also become an effective means for forcing governments to involve Aboriginal peoples in decision-making, especially in regard to resource development on their claimed territories. As consultation must take place with Aboriginal representatives who have the authority to act on behalf of their peoples, the process of consultation itself is an exercise of self-government, and a way for Aboriginal peoples to assert and establish government-to-government relationships.

\footnotetext{
$185 \quad$ Sparrow, above n 170, 1119.

186 Haida Nation v British Columbia [2004] 3 SCR 511; Taku River Tlingit First Nation v British Columbia (Project Assessment Director) [2004] 3 SCR 550. The duty to consult also applies in the context of treaty rights: Mikisew Cree First Nation v Canada (Minister of Canadian Heritage) [2005] 3 SCR 388.

187 Haida Nation, above n 186, para 39. For detailed analysis and subsequent case law, see M Morellato, 'The Crown's Constitutional Duty to Consult and Accommodate Aboriginal and Treaty Rights', February 2008, at: fngovernance.org/pdf/CrownDuty_MM_0208.pdf. Policy, 1945-1960 (University of New Mexico Press, 1986), and Benjamin Richardson's chapter on US Indian Law.
} 


\section{CONCLUSIONS}

This discussion has revealed that, despite their common British heritage and legal traditions, the United States, Canada, Australia and New Zealand have developed divergent legal doctrines in relation to Indigenous land rights. Differences in the content and requirements for proof of these rights stem largely from differences in judicial opinion over their source.

In the United States and Canada, the courts have ruled that occupation is the source of Indigenous title, but the American approach has distinctly territorial and jurisdictional dimensions, whereas the Canadian approach is more narrowly proprietary. In the United States, Indian nations have both residual sovereignty and land rights in the territories occupied by them. By contrast, the Canadian Supreme Court has determined that Aboriginal title is a property right arising from occupation of land that is separate from governance rights. And yet the Court has acknowledged that Aboriginal nations have decision-making authority over their collectively-held lands, authority one Canadian judge has concluded is governmental in nature.

In Australia and New Zealand, the courts have decided that Indigenous land rights stem from the Indigenous legal systems that existed prior to British acquisition of sovereignty. Through the doctrine of continuity, these rights became enforceable in common law courts. Unfortunately, in applying this doctrine the Australian judiciary has required strict proof that traditional laws and customs confer specific rights, and that knowledge and observance of the laws and customs have continued up to the present. These requirements have narrowed the scope of claimable rights, and imposed impossible burdens of proof on some Indigenous claimants. In New Zealand, application of the doctrine of continuity has been less problematic, as land rights stem from tikanga Māori, broadly defined as including both custom and usage. Nor is proof of continuous observance of tikanga Māori necessary, except where required by statute.

The authority of non-Indigenous governments to extinguish or infringe Indigenous land rights is dependent on a nation-state's constitution. In the four jurisdictions examined here, these rights are most vulnerable to legislative extinguishment and infringement in New Zealand because the unicameral Parliament has sole authority over them. In the 
United States and Canada, exclusive federal jurisdiction over Indigenous affairs provides some protection against the states and provinces. In Australia, federalism also provides some protection against the states, to the extent that the Commonwealth Parliament legislates in favour of Indigenous land rights. Only in Canada are land rights generally protected against legislation by a specific constitutional provision. Ultimately, however, the fate of Indigenous rights depends on the vision of judges, the political will of legislators, and a belief within the larger community that justice requires that these rights be maintained and respected. 